\title{
CRYSTALLIZATION OF THE QURAN: AN ANALYSIS OF JOHN WANSBROUGH'S THEORY
}

\author{
Ahmad Sanusi Azmi \\ Fakulti Pengajian Quran Sunnah, Universiti Sains Islam Malaysia, \\ Bandar Baru Nilai, 71800, Nilai, Negeri Sembilan, Malaysia. \\ E-mail: sanusi@usim.edu.my
}

\begin{abstract}
In the early nineteenth century, modern scholars started to explore materials of Quranic studies through the historical criticism approach. New arguments were presented in challenging the traditional account of the formation of the Quran with a various range of theory. It seems that the most radical assessment was demonstrated by John Wansbrough in his exceptional works "Quranic Studies: Sources and Methods of Scriptural". The literary analysis which was used by John Wansbrough in his Quranic study discovered a new theory about the history of Quranic formatian. This article aims to explore the theory of late crystallization of the Quran as proposed by John Wansbrough. This study is a qualitative research uses the study of the comparative and textual analysis. The result study asserts that Wansbrough's theory is a new discovery which given an impact and a new path in the Quranic studies. His conclusion is not accepted by all scholars. Some scholars regarded Wansbrough's evidence that he used as an argument is not absolutely convincing.
\end{abstract}

\section{Keywords:}

Quran; criticism; John Wansbrough; crystallization.

\begin{abstract}
Abstrak
Pada awal abad kesembilan belas, sarjana moden telah mulai menggali bahan-bahan terkait kajian al-Qur'an melalui pendekatan kritik sejarah. Pelbagai argumen baru telah dilontarkan dalam menilai sejarah pembentukan dan penulisan Alquran. Salah satu penilaian serta kritik yang paling radikal telah dihasilkan oleh John Wansbrough melalui karyanya yang berjudul "Quranic Studies: Sources and Methods of Scriptural". Kajian kesusasteraan yang dilakukannya terhadap Alquran telah menghasilkan penemuan baru terkait sejarah pembentukan Alquran. Artikel ini bertujuan mengkaji teori John Wansbrough tentang kristalisasi Alquran yang terbentuk melalui proses lama dan panjang. Kajian ini merupakan penelitian kualitatif dengan menggunakan metode analisis teks dan perbandingan. Hasil kajian ini menegaskan bahwa teori yang digunakan oleh John Wansbrough adalah sesuatu yang baru dan memberikan dampak terhadap kajian Alquran. Namun, teori yang digunakannya tidak sepenuhnya diterima oleh semua sarjana modern, sebagian sarjana menganggap temuan tersebut kurang meyakinkan.
\end{abstract}

\section{Kata Kunci:}

Quran; kritik; John Wansbrough; pembentukan Alquran.

DOI: $10.15575 / \mathrm{jw} . \mathrm{v} 2 \mathrm{i} 2.1611$

Received: September 2017; Accepted: December 2017; Published: December 2017 


\section{A. INTRODUCTION}

Indeed, it is not an easy task to explore the historical aspect of the Quran through the modern scientific approaches. ${ }^{1}$ The theory adduced by John Wansbrough (1928-2002) in the 1980s has brought the discourse of this respected field to a new level. Taken together all his literary analysis on the Quran, John Wansbrough argues that neither the Quran nor Islam was originated from Muhammad, not even the product of Arabia. ${ }^{2} \mathrm{He}$ argues that the Quran was only crystallized to its final form no earlier than the third/nine century. The origin of its content, he believed, was a mixture of different kinds of materials ${ }^{3}$, emanated from different types of communities which were located not in Arabia. Portraying his conclusion, he clearly said that: "Logically, it seems to me quite impossible that canonization should have preceded, not succeeded, recognition of the authority of scripture within the Muslim community. Chronologically, the data of Arabic literature cannot be said to attest to the existence of the canon before the beginning of the third/nine century.",

Wansbrough, however, believed that the pre-canonical Quran has existed in the form of prophetic logia, the term initiated by him. The various set of similar prophets' stories, in difference length and diverse vocabulary in the Quran support this idea. According to him, "the repetitions and apparent contradictions within the Quran indicate that the logia achieved a measure of canonicity in several communities prior to the canonization of the

\footnotetext{
${ }^{1}$ Ahmad Sanusi Azmi, “The Intricate Labyrinth Of Qur'ānic References in Sīrah Nabawiyyah: An Overview of The Orientalist Works," Journal Of Hadith Studies 1, no. 1 (2016), 1-5, http://journalofhadith.com/index.php/johs/article/view/3.

${ }^{2}$ Herbert Berg, "The implications of, and opposition to, the methods and theories of John Wansbrough," Method \& Theory in the Study of Religion 9, no. 1 (1997), 8.

3 John Wansbrough, Quranic Studies: Sources and Methods of Scriptural Interpretation (New York: Prometheus Books, 2004), 12.

4 Wansbrough, Quranic Studies: Sources and Methods of Scriptural Interpretation, 202.
}

Quran". 5 This assorted logia originated from different kinds of communities, developed in their unique sectarian atmosphere ${ }^{6}$ (an atmosphere consisting the Christians and Jews that surrounded, interacted and influenced to the emergence of the new Arab religion), in the region of Fertile Crescent, have altogether integrated to develop and form the Muslim's scripture. This novel conclusion was established by Wansbrough's delicate observation on the literary nature of the Quran (Indeed, this novel finding is totally contradicting the traditional views on the origin of the Quran by non-Muslim themselves). ${ }^{7}$ His reading has also contributed to the delineation of the nature of its origin. Believing that there is no ur-text (an original or the earliest version of a text) for the Quran, he proposed a picture of its composition by saying that "Exhibiting a comparatively limited lexical range, those formulae serve to confirm the impression of a composition made up of originally unrelated periscopes." 8

\section{B. RESULT AND DISCUSSION \\ 1. Discussing The Theory of John Wans- brough}

Wansbrough's notion concerning the formation of the Quran has not been mere accepted neither it was completely rejected. Before accepting his new conclusion, one could stumble to understand what he really means in his writings. Maintaining a high level of academic English, his books were embellished

\footnotetext{
5 Wansbrough, Quranic Studies: Sources and Methods of Scriptural Interpretation, 50-51.

6 Wansbrough, Quranic Studies: Sources and Methods of Scriptural Interpretation, 20.

${ }^{7}$ Ahmad Sanusi Azmi et al., "From Christianity to Islam: An Analysis of Ibn Rabban's Approach towards Sira Nabawiyya," International Journal of Islamic Thought 11, no. 1 (30 May 2017), 1-5, doi:10.24035/ijit.11.2017.001. See also Ahmad Sanusi Azmi et al., "Kritikan Terhadap Rasulullah Dan AlQuran: Analisis Karya Non-Muslim Zaman Umawiyyah Dan Abbasiyyah," Journal of Hadith Studies 2, no. 1 (Juni 2017): 18-30.

${ }^{8}$ Azmi et al., "Kritikan Terhadap Rasulullah Dan Al-Quran: Analisis Karya Non-Muslim Zaman Umawiyyah Dan Abbasiyyah."
} 
with Arabic font, Hebrew scripts, Greek and Latin terms which totally require readers to be familiar with the academic discourse. His thought was delivered in a heavy word, even the academicians in this field demonstrate a different understanding while analyzing his term. For instance, Herbert Berg define his prophetic logia (concepts or ideas attributed to the prophets) as a logia developed as a series of uncoordinated periscopes to meet the liturgical and didactic needs of a group, ${ }^{9}$ while Fred Donner presuming that this term is referring to Hadith, ${ }^{10}$ whereas Gabriel Reynolds portrays the term concisely as "homiletic sayings". "11 Moreover, some scholars like Charles Adams, ${ }^{12}$ G.H.A Juynboll, ${ }^{13}$ and W. Graham have sincerely confessed the difficulty to communicate with this notion.

Wansbrough developed his evident of the late canonization of the Quran by an argument from silent (argumentum a silentio), asserting that there is no reference to the Quran in Fiqh Akbar I, written by Abu Hanifa (AH 150) (dated by Wensinck to about the middle of second/eighth century). ${ }^{14}$ This idea implies that the important book such this, where the major discussion about Muslim creed

\footnotetext{
${ }^{9}$ Berg, "The implications of, and opposition to, the methods and theories of John Wansbrough.", 8.

10 Donner said, by "Prophetical Logia" he presumably means sayings by and about the Prophetwhat we usually call Hadith. See, Fred M Donner, Narratives of Islamic Origins The Beginnings of Islamic Historical Writing (New Jersey: The Darwin Press, 1998), 36.

11 Gabriel Said Reynolds, The Quran In Its Historical Context (London: Routledge, 2008), 14.

12 Borrowing Adams words, he said that: "Frankly, there is much in what he has written that I do not understand or whose relevance to his argument escapes $m e$ " in Charles J. Adams, "Reflections on the work of John Wansbrough," Method \& Theory in the Study of Religion 9, no. 1 (1 January 1997), 76, doi:10.1163/157006897X00061.

13 Gautier H.A Juynboll, "Review of John Wansbrough, Quranic Studies: Sources and Methods of Scriptural Interpretation," Journal of Semitic Studies 24, no. 2 (1979), 293-296.

14 Wansbrough, Quranic Studies: Sources and Methods of Scriptural Interpretation, 44.

Wansbrough, Quranic Studies, 44.
}

presented here, should not be absent from mentioning verses from the Quran. The lack of Quranic references in this essential book suggests that the Quran at that particular time was not reached its ne varietur status yet. Examining Wansbrough's argument, Adams proposes an alternative view of this idea. According to his analysis, Fiqh Akbar I was written in the sectarian conflict atmosphere where this book was aiming to certain groups such as Khawarij or Jahmiyyah as its audience, where the central issue was not requiring heavy references to the Quran, rather dealing with the theological issues raised by the community. Thus, the absent or lack of references to the Quran does not necessarily denying the existence of the Quran as a closed corpus at that time. ${ }^{15}$ On the other hand, Juynboll adduced another book, namely as al'Alim wa al-Muta'alim and Risalah ilä Uthman al-Batti, both ascribed to Abu Hanifa, which could facilitate us in giving a clear picture of the number of references to the Quran in the works attributed to Abu Hanifa. Moreover, he presented another significant text which was attributed to Hasan ibn Muhammad al-Hanafiyya (100 AH). This work was published by Van Ess in Arabica. $\mathrm{He}$ argues that "If that risala can be proved to be authentic, it totally undermines Wansbrough's theory since it contains many quotations from the Quran."16

It seems to me that the amount of Quranic references loaded in such scholarly works would not merely disprove Wansbrough's theory since he himself concedes the existence of these Quranic verses in form of prophetic logia. However, it is also hard to accept his theory by relying on the lack of Quranic references in the early Muslim works since there is no convincing explanation on how these references or prophetic logia evolved to be the crystallized scripture. It could probably

\footnotetext{
15 Adams, "Reflections on the work of John Wansbrough.”, 84.

${ }^{16}$ Juynboll, "Review of John Wansbrough, Quranic Studies: Sources and Methods of Scriptural Interpretation.”, 295.
} 
a mere postulation as proposed by previous scholars. ${ }^{17}$ How exactly the development process was not made clear, who the authority that selected the prophetic logia from diverse communities was nowhere indicated, and how the Quran has redacted it in distinctive shape (Makkī/Madanīi) had never been explained.

While Adams and Juynboll arguing his argumentum a silentio, Graham ${ }^{18}$ and Donner arguing the process of late crystallization of the Quran which takes almost two centuries. Based on his analysis on the certain passages that repeating the similar stories in variant vocabulary, Wansbrough's suggestion that the nature of repetition in the Quran indicates a slow and long process of evolution to develop a solid closed text as we have it today. Donner asserts that even if one agrees with Wansbrough scrupulous judgment, it remains possible that the development he posits could have taken place within thirty years, rather than two hundred. ${ }^{19}$

\section{Implication of John Wansbrough's Works}

If Wansbrough's theory regarding the late crystallization of the Quran is to be accepted, the implication would be completely enormous. Any effort to establish engagement between Muhammad and the Quran seems to be impossible since according to Wansbrough's view, the Quran was not originated from him, not in his time and not even in the Hijaz. Any scholarly works related to its historicity (such as al-Naskh wa alMansükh) ${ }^{20}$ and the traditional chronology of

17 Ahmad Sanusi Azmi, "Dakwaan Orientalis Terhadap Pengaruh Kristian Dalam Al-Quran: Satu Penelitian," Jurnal Darul Quran 16 (2012), 141-66.

18 William A. Graham, "Review of John Wansbrough, Quranic Studies: Sources and Methods of Scriptural Interpretation," Journal of the American Oriental Society 100, no. 2 (1980), 137-41.

${ }^{19}$ Fred M Donner, Narratives of Islamic Origins The Beginnings of Islamic Historical Writing (Princeton: The Darwin Press, 1998), 37.

${ }^{20}$ Abrogation. In Quranic context, it refers to the process by which some of the Quran's earlier verses are said to have been annulled by later revelations. its revelation is no longer valid. The prevalent distinctive nature of its verses and chapters, namely as Makki and Madani will be invalidated as well since its definition was solely based on Muhammad's Hijra. It cannot be imagined, how the scholar works, both Islamic or western scholarship, (such as Noldeke, Schwally, Bergsträsser, Pretzl, Burton, Bell, Watt and others) who spent their effort in Quranic studies based on the historicity and chronology arrangement of the Quran, would expose to be nullified. Motzki firmly conclude that

If Wansbrough's theory is accepted, there is no way to establish anything of the revelation or the life of the historical Muhammad from Quran, Sira, Tafsir or Hadith. To look for historical facts in this sort of literature would be a meaningless research exercise. $^{21}$

\section{Nevo's Work Supporting Wansbrough's Theory}

Wansbrough's theory did really give an impact; shed a novel spot and making a new path in the Quranic studies. Even though his conclusion was not being accepted universally, some of the modern researchers are applying the radical methods introduced by him in the field of Prophet's Sira. Utilizing Wansbrough's radical thinking, a group of modern researcher argue the existence of Muhammad, in order to reconstruct a historical portrait of the Prophet's life. This group of proficient researchers resolutely established their argument on the premise that there is no convincing material evidence to confirm the traditional account recorded by Muslim, or even some of the physical evidence revealed by them seems to be

\footnotetext{
Abdullah Saeed, The Quran: An Introduction (London: Routledge, 2008), 170.

21 Harald Motzki, "Alternative accounts of the Qur'àn's formation," in The Cambridge Companion to the Qur'an, ed. oleh Jane Dammen McAuliffe (Cambridge: Cambridge University Press, 2006), 62, doi:10.1017/CCOL0521831601.004.
} 
contradicted with the prevalent traditional account.

Among Wansbrough's supporters is Yehuda Nevo, an Israeli archaeologist who spent much of his career studying early Arabic inscriptions in the Negev desert. Unlike Wansbrough, who relied on literary analysis of the Quran and exegetical literature, Nevo based his theories on the religious terminology in those inscriptions. Employing archaeological, numismatic and epigraphic evidence, Nevo summarized similar conclusion as proposed by Wansbrough, which is the development of Quran is the outcome of a slow and long process of construction spanning two centuries or more. The lack of material evidence embolden Nevo to offer a radical thesis by proposing that the popular occasions in Sirah or even Muhammad and the first four caliphs are actually the characters of myth. This notion was initiated based on the absence of valid hard evidence that can be attributed to Muhammad. The earliest archaeological evidence that recognize Muhammad as a prophet was only appeared around 690AC. Even though Muhammad's name was minted in the coins discovered in the seventh century, Nevo argues that the word should be read as an adjective rather than a noun, denying the historicity of Muhammad as a person.

Explaining his theory, Nevo believed that there is no Islamic conquest at all. What was really happen according to him is that the Byzantium intentionally withdrew her forces from the Arab region as a part of their administrative policy. At the same period, the emperors systematically equipped the Arab tribes in Syria/Palestine in preparation for Byzantium eventual withdrawal. In the gradual process of withdrawal, the Arabs rise to rebel Byzantium government. He seems to portray that the Muslim conquest was actually the Arab rebellion on the Byzantium Empire, saying that:

The final act of disassociation from the provinces (the barbarian invasion, the popular rebellion) which history records as the sole reason for it, is actually only the tip of the iceberg. ${ }^{22}$

Nevo believed that the rebel Arab have to invent a new religious concept in order to substantiate an official religion for their growing empire. After becoming a new ruler of provinces, Muhammad's name was minted in their coin in order to reach their goal (which is to develop a new religion and its figure). To flush the remaining influences of Byzantium, this step seems to be a part of an oblique campaign of anti-Christian right after the withdrawal of Byzantium forces from their provinces. In the other word, minting the word of Muhammad was just not only to demonstrate a new religion for a new country but also as an alternative way to stimulate the creed of monotheism and to deny the concept of Trinity, a new concept of religion for a new developing power. While discussing the Quran's origin, Nevo presented his argument using his rigorous methodology. In the light of Arabic inscriptions and the nature of the Quran itself, Nevo and Koren believed that the Quran is a blend of various small texts with the Bible as a reference works. The long process of embodiment has shaped the Quran to its final form in Iraq and not in Hijaz. This theory was developed based on the numerous Quran's reference to regular rains and date palms.

\section{Reflection on Nevo's Thesis}

Nevo's proposal has automatically captured people attention, not only because of its radical judgment but also its novel approach. A number of scholars have presented a remarkable thought on this astonishing thesis. Most of them admired Nevo and Koren's methods in reassessing the Muslim traditional account regarding the origin of Islam. However, some of them have posed a profound challenge to their notable theory. Donner argues the accuracy of Negev and Al-Sam to be the centre of the emergence of Islam rather than Hijaz. Quoting his word, he wrote “

\footnotetext{
${ }^{22}$ Yehuda D Nevo and Judith Koren, Crossroad to Islam (New York: Prometheus Books, 2003), 21.
} 
Recently, Yehuda Nevo has analyzed the content of a number of early Arabic inscriptions from the Negev and elsewhere in geographical Syria and concluded that the information in them seems to support Wansbrough's theory of the Quran's codification, both as to date (relatively latesecond or third century $\mathrm{AH}$ ) and place (Fertile Crescent, rather than Arabia). His argument, however, is circular. The absence of specifically Quranic or Muslim phraseology from the generic monotheism of the earliest Negev texts, which he carefully demonstrates, may be taken as evidence for late codification of the Quran only if we knew that the Quranic text crystallized in this region (i.e. the Negev, or at least geographical Syria) rather than somewhere else, such as Arabia; but the crystallization of the Quran outside Arabia is merely another of Nevo's (and Wansbrough's) assumptions, not a known fact.",23

In some cases, the material evidence employed by them seems fragile to support the thesis; in the other way it could be taken equally as supporting proof to validate the traditional account. For example, Bamyeh noted that Muawiyyah's dam inscription has been used to prove the existence of indeterminate monotheism rather than Islam. Even though, the inscription does not contain the word of Muhammad, it itself dated according to the Hijra calendar. ${ }^{24}$ Apart from that, the interpretation of material evidence could be sometimes subjective, depending on personal's perspective. For example, one would argue why must the word Muhammad in this remains be understood as an adjective rather than a noun and how then this adjective word evolved to be a fictional figure in a vast num-

23 Donner, Narratives of Islamic Origins The Beginnings of Islamic Historical Writing, 62-63.

${ }^{24}$ Mohammed A Bamyeh, "Review of Crossroads to Islam: The Origins of the Arab Religion and the Arab State by Yehuda D. Nevo and Judith Koren," International Journal of Middle East Studies 38, no. 2 (2006): 303-4, doi:10.1017/S0020743806212364. ber of references in Muslim and non-Muslim account.

Furthermore, the recent physical evidence discovered by other scholars could easily discard Nevo's theory. The ongoing paleographical work on San'a manuscript could provide another significant revelation. According to Puin, a vast number of the manuscript could be a hundred years older than Islam ${ }^{25}$ indicates the probability of early existence of the Quran. If the manuscripts contain a clear word of Muhammad, Nevo's thesis then ought to be reviewed.

Interestingly, Crone, with her critical reinterpretation of Islam's origin expressed a different view regarding to the existence of Muhammad. In one of her article, she evidently said that "There is no doubt that Mohammed existed, occasional attempts to deny it notwithstanding". ${ }^{26}$ However, the outstanding work presented by them deserved a great appreciation. It is not an easy task to entice the public and scholars to reassess their firm belief. Nevo and Koren successfully did it with their excellent methodology. Their work induces the others to run another scrutinization in order to find what was really happening in the sixth and seventh centuries.

\section{The Implication of The Theory}

Some of the modern researchers believed that Muhammad has existed but the Quran seems to be a later development of Muslim intellecttual product. The references of $\mathrm{Mu}$ hammad in the Quran made by Muslim were a later development and Thereforee it does not reflect a real picture of Muhammad life nor does it confirm what was really happen as narrated in Muslim traditional sources. In some circumstances, the details engraved in this scripture does not necessarily support the

\footnotetext{
${ }^{25}$ Toby Lester, "What Is the Koran?," The Atlantic, accessed July 8, 2017, https://www.theatlantic.com/magazine/archive/1999/01/what-is-thekoran/304024/?single_page $=$ true.

26 Patricia Crone, "What Do We Actually Know about Mohammed?," open Democracy, accessed July 9, 2017, https://www.opendemocracy.net/faith-europe_islam/mohammed_3866.jsp.
} 
narration recounted in the Sirah. It is Muslim exegesis that connects the fact stated in the Quran with the Sirah of Muhammad.

The prevalent interpretation of the Quran chapter 93 could be one of the instances:

By the morning hours. And by the night when it is stillest. Thy Lord hath not forsaken thee nor doth He hates thee. And verily the latter portion will be better for thee than the former. And verily thy Lord will give unto thee so that thou wilt be content. Did He not find thee an orphan and protect (thee)? Did $\mathrm{He}$ not find thee wandering and direct (thee)? Did He not find thee destitute and enrich (thee)? Therefore the orphan oppress not. Therefore the beggar drives not away. Therefore of the bounty of thy Lord be thy discourse.

The data in this Quranic chapter is crystal clear. According to the Muslim exegetes, this chapter is dedicated entirely to Muhammad. It is a message from Allah which touches his heart with pleasure, tranquillity and contentment. Muslims historians employ this chapter as a basis to portray the Prophet's youth time as an orphan, needy and in error. On the other hand, if we analyze throughly, this chapter does not necessarily refer to Muhammad. According to Rippin, there is nothing absolutely compelling about interpreting this chapter in light of the life or lifetime of Muhammad. The "thee" of this passage does not have to be Muhammad. It certainly could be but it does not have to be. ${ }^{27}$

To a certain degree, this notion does make sense. However, if we accept this theory, then who is the addressee in this passage? And more perplexing question is if the entire verses consisting of "you" and "thee" should not to be interpreted in the light of Muhammad life, then to whom this kind of verses is addressed to? Rippin deduces to a conclusion that the difficulties in identifying the addressee in the

${ }^{27}$ A. Rippin, "Muhammad in The Quran: Reading Scripture in The 21st Century," in The Biography of Muhammad: The Issue of the Sources, ed. H. Motzki (Leiden/Boston/Koln: Brill, 2000), 299.
Quran as a rushed composition, compilation and editing of the text.

\section{CONCLUSION}

It is beyond doubt that Wansbrough's theory did give an impact; shed a novel spot and making a new path in the Quranic studies. His conclusion is however not being accepted universally, and in fact, it probably reaches the outer realms of possibility and plausibility. Some of his evidence have been argued scholarly by academicians who regarded his argument as not absolutely convincing. Questions posed by Donner, Juynboll and others need more critical analysis in order to examine the theory suggested by Wansbrough.

\section{REFERENCES}

Adams, Charles J. "Reflections on the work of John Wansbrough." Method \& Theory in the Study of Religion 9, no. 1 (Januari 1997): 75-90. doi:10.1163/157006897X00061.

Azmi, Ahmad Sanusi. "Dakwaan Orientalis Terhadap Pengaruh Kristian Dalam AlQuran: Satu Penelitian.” Jurnal Darul Quran 16 (2012): 141-66.

. 'The Intricate Labyrinth Of Qur'ānic References in Sīrah Nabawiyyah: An Overview of The Orientalist Works." Journal Of Hadith Studies 1, no. 1 (2016): 1-6.

Azmi, Ahmad Sanusi, Mohd Yusuf Ismail, Zulhilmi Mohamed Nor, dan Amiruddin Mohd Sobali. "Kritikan Terhadap Rasulullah Dan Al-Quran: Analisis Karya Non-Muslim Zaman Umawiyyah Dan Abbasiyyah." Journal of Hadith Studies 2, no. 1 (Juni 2017): 18-30.

Azmi, Ahmad Sanusi, Zulhilmi Mohamed Nor, Amiruddin Mohd Sobali, Mohd Yusuf Ismail, dan Amran Abdul Halim. "From Christianity to Islam: An Analysis of Ibn Rabban's Approach towards Sira Nabawiyya." International Journal of Islamic Thought 11, no. 1 (Mei 2017): 15. doi:10.24035/ijit.11.2017.001.

Bamyeh, Mohammed A. "Review of Crossroads to Islam: The Origins of the 
Arab Religion and the Arab State by Yehuda D. Nevo and Judith Koren." International Journal of Middle East Studies 38, no. 2 (2006): 303-4. doi:10.1017/S0020743806212364.

Berg, Herbert. "The implications of, and opposition to, the methods and theories of John Wansbrough." Method \& Theory in the Study of Religion 9, no. 1 (1997): 3 22.

Donner, Fred M. Narratives of Islamic Origins The Beginnings of Islamic Historical Writing. New Jersey: The Darwin Press, 1998.

Graham, William A. "Review of John Wansbrough, Quranic Studies: Sources and Methods of Scriptural Interpretation." Journal of the American Oriental Society 100, no. 2 (1980): 137-41.

Juynboll, Gautier H.A. "Review of John Wansbrough, Quranic Studies: Sources and Methods of Scriptural Interpretation." Journal of Semitic Studies 24, no. 2 (1979).

Motzki, Harald. "Alternative accounts of the Qur'ān's formation." Dalam The Cambridge Companion to the Qur'an, diedit oleh Jane Dammen McAuliffe, 5976. Cambridge: Cambridge University Press, 2006. doi:10.1017/CCOL0521831601.004.

Nevo, Yehuda D, dan Judith Koren.
Crossroad to Islam. New York: Prometheus Books, 2003.

Reynolds, Gabriel Said. The Quran In Its Historical Context. London: Routledge, 2008.

Rippin, A. "Muhammad in The Quran: Reading Scripture in The 21st Century." Dalam The Biography of Muhammad: the issue of the sources, diedit oleh $\mathrm{H}$. Motzki. Leiden/Boston/Koln: Brill, 2000.

Saeed, Abdullah. The Quran: An Introduction. London: Routledge, 2008.

Wansbrough, John. Quranic Studies: Sources and Methods of Scriptural Interpretation. New York: Prometheus Books, 2004.

\section{INTERNET}

Patricia Crone. "What Do We Actually Know about Mohammed?" open Democracy. Accessed July 9, 2017. https://www. opendemocracy.net/faith-europe_islam/ mohammed_3866.jsp.

Toby Lester. "What Is the Koran?" The Atlantic, t.t. Accessed July 8, 2017. https://www.theatlantic.com/magazine/arch ive/1999/01/what-is-the-koran/304024/? single_ page $=$ true. 